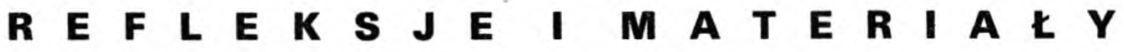

\section{Michał Wojciechowski}

\section{UMYCIE NÓG UCZNIOM (J 13, 1-20)}

Zawarty w czwartej Ewangelii opis umycia uczniom nóg przez Jezusa należy do tych pozornie dobrze znanych tekstów biblijnych, które przy bliższym zbadaniu okazują się niełatwe do zrozumienia. Opowiadanie nie jest gładkie. Przebieg wydarzeń i przekazane przez Ewangelię brzmienie słów Jezusowych prowadzić mogą do rozmaitych interpretacji zaskakującego czynu Jezusa. Jedni egzegeci podkreślają przede wszystkim sens przykładu miłości, pokory i służby, inni sens sakramentalny (skojarzenia z chrztem i z pokutą a także z przygotowaniem do Eucharystii), jeszcze inni sens zbawczy (np. zapowiedź Krzyża, przyjęcie do chwały z Chrystusem, wejście na ucztę eschatologiczną). Łączy się to z różnymi opiniami na temat powstania obecnego tekstu J 13, 1-20, na temat jego pierwotnego rdzenia i sposobu opracowania redakcyjnego. Jest bowiem widoczne, że opowiadanie łączy elementy różnego typu, dając $w$ ten sposób pewną podstawę dla interpretacji rozbieżnych. Jak to uporządkować?

Jak zauważa Rudolf Schnackenburg w swoim komentarzu do Ewangelii św. Jana, przy badaniu tego tekstu bez krytyki literackiej nie można się obyć (t. 3, s. 7). Koniecznym punktem wyjścia dla wyjśnienia sensu czynności zamierzonego przez Jezusa wydaje się więc wyodrębnienie warstwy najstarszej oraz ewentualnych rozwinięć i komentarzy późniejszych. Przy tej analizie niezbędne jest odwołanie się do wiedzy o ,języku Janowym”, a szczególnie do częstości używania pewnych wyrazów i konstrukcji przez tę Ewangelię. Właśnie to pozwoli odróżnić rdzeń opowiadania od zdań wychodzących w swej obecnej formie spod pióra ewangelisty. W części zdań bowiem występuje Jego wysoce charakterystyczny styl w części zaś nie.

Najpełniejsze dane statystyczne o języku czwartej Ewangelii zgromadzili M.-E. Boismard i A. Lamouille w tomie 3. Synopsy w języku francuskim. Przedstawiona na podstawie tych danych hipotetyczna rekonstrukcja dziejów pisania Ewangelii nie spotkała się jednak z powszechniejszym uznaniem. Przy samej perykopie J. 13, 1-20 istnieje kilka innych przypuszczeń co do jej historii redakcji. Zamiast je przedstawiać osobno, lepiej skupić się na istniejących danych na temat poszczególnych słów i zwrotów, starając się odróżnić elementy pierwotne od opracowania. Potem będzie można określić sens czynności Jezusa oraz zastanowić się nad opracowaniem perykopy przez ewangelistę.

Dokładna analiza musi oczywiście odwoływać się do oryginału greckiego. Dla zwiększenia czytelności wywodu podamy najpierw możliwie dosłowny przekład perykopy. 
13,1 Przed świętem Paschy Jezus wiedząc, że nadeszła jego godzina przejścia z tego świata do Ojca, umiłowawszy swoich w świecie, do końca ich umiłowal ${ }^{2}$. A podczas wieczerzy, gdy diabel już nakłonił do wydania Go serce Judasza Iskarioty, syna Szymona ${ }^{3}$, wiedząc, że wszystko dał mu Ojciec w ręce i że od Boga wyszedl i do Boga odchodzi -

${ }^{4}$ Wstał od wieczerzy i złożył szaty, a wziąwszy prześcieradło opasał się ${ }^{5}$. Następnie nalał wody do miski i zaczął myć nogi uczniów i wycierać prześcieradłem, którym był opasany. ${ }^{6}$ Gdy więc podszedł do Szymona Piotra, (ten) mówi mu: Panie, ty mi myjesz nogi?!? Odpowiedział Jezus i rzekł mu: Co ja czynię, ty nie wiesz teraz, zrozumiesz zaś potem ${ }^{8}$. Mówi mu Piotr: Nie będziesz mi mył nóg, na wieki! Odpowiedział Jezus mu: Jeśli ci nie umyję, nie masz udziału ze mną9 . Mówi Piotr: Panie, nie tylko nogi, ale i ręce i głowę!

${ }^{10}$ Mówi mu Jezus: Wykąpany nie potrzebuje się myć, (oprócz nóg), ale jest czysty cały. A wy czyści jesteście, ale nie wszyscy ${ }^{11}$. Wiedział bowiem, kto go wyda, dlatego rzekł „nie wszyscy czyści jesteście”.

${ }^{12}$ Kiedy wiẹc umył ich nogi, wziął swe szaty i znów spoczął, rzekł im: Czy rozumiecie co wam uczynilem?

${ }^{13}$ Nazywacie mnie Nauczycielem i Panem i dobrze mówicie, bo nim jestem ${ }^{14}$. Jeżeli ja umyłem wam nogi, Pan i Nauczyciel, to i wy powinniście myć nogi sobie nawzajem ${ }^{15}$. Przykład bowiem wam dałem, jako ja uczynilem wam, i wy czyńcie ${ }^{16}$. Zaprawdę, zaprawdę mówię wam: Sługa nie jest większy od swego pana, ani wysłannik większy od tego, który go posłal.

17Jeśli to wiecie, szczęśliwi jesteście - jeżeli to czynić będziecie.

${ }^{18} \mathrm{Nie}$ o wszystkich $\mathrm{z}$ was mówię, ja wiem, kogo wybrałem. Ale żeby się wypełniło Pismo: „Kto ze mną spożywa chleb, ten podniósł na mnie piętę" zanim to się stanie, abyście, kiedy się to stanie, uwierzyli, że ja jestem.

${ }^{20}$ Zaprawdę, zaprawdę powiadam wam: Kto przyjmuje tego, kogo posyłam, mnie przyjmuje, a kto mnie przyjmuje, przyjmuje tego, który mnie posłał.

\section{ANALIZY JEZYKOWE I ZNACZENIE POJEDYNCZYCH ZDAŃ}

W. 1-3 stanowią wprowadzenie do całej drugiej części Ewangelii (rozdz. 13-20), będąc tym samym dziełem ewangelisty. W. 1 i 3 pełne są typowo Janowych terminów teologicznych. W. 2 nawiązuje do dalszego ciągu całości, opisanej w następnej perykopie zdrady Judasza (zamysł kompozycyjny). Pierwotny początek opowiadania o umyciu nóg mógł zawierać samo określenie czasu („przed Paschą").

W. $4-5$ to centralny punkt perykopy, jej niewątpliwy rdzeń. W wierszach tych znaleźć można szereg słów rzadkich i wolne są one od wpływu „stylu Janowego".

W. 6-10 natomiast zawierają liczne elementy tego stylu, są więc przez wielu autorów przypisane ewangeliście. Jest to jednak nie całkiem słuszne. Wyrażenia „Janowe” skupiają się bowiem w narracji, w krótkich wprowadzeniach do zdań dialogu. Można ich tam wyliczyć aż 9 (na 27 słów): greckie oun („więc”) jako łącznik; 2 razy „Szymon Piotr” (17 razy u Jana i tylko 3 razy gdzie indziej w NT); 2 razy "mówi mu” (odpowiednio 53 i 23 razy; legei auto po grecku); „odpowiedział (...) i rzekł” (apekrithe... kai eipen: 29+2); „odpowiedział (...) mu” (apekrithe... auto: $45+12$ ); 2 razy „mówi mu (...) Panie” (legei auto... Kyrie: $9+0$, tylko u Jana).

Zdania wstępne należą więc do warstwy redakcyjnej. W samych zdaniach dialogu natomiast cech stylu Janowego jest wyraźnie mniej. Trzeba je rozpatrzyć osobno. 
W. 6: „(Panie), ty mi myjesz nogi”. Protest Piotra ma wszelkie cechy autentyczności. Słowo „Panie” bierzemy jednakowoż w nawias, ponieważ wraz z wprowadzeniem cytatu może ono (choć nie musi), pochodzić spod pióra ewangelisty, chcącego uwypuklić przyczynę zdumienia Piotra: oto Pan chce mu myć nogi!

W. 7. Odpowiedź Jezusowa „Co ja czynię, ty nie wiesz teraz, zrozumiesz zaś potem" zbudowana jest w stylu Janowym. Konstrukcje „ja (...) ty" (ego...sy) i ,ty nie wiesz” (sy ouk oidas) mają w Ewangelii liczne analogie. „Ja” w ustach Jezusa jest w niej szczególnie częste i akcentowane. Samo „,ja” przeciwstawione „ty" nie jest charakterystyczne, typowe są jednak sekwencje „ja (...) wy" (ego... hymeis: 17+1) oraz „wy nie wiecie" (hymeis ouk oidate: $7+0$ ). Mamy tu po prostu ich wariant w liczbie pojedyńczej. Występują też słowa u Jana nieco częstsze niż gdzie indziej ,wiedzieć” (oida) i „teraz” (arti). Bylaby zatem ta część dialogu wprowadzona przez ewangelistę, w tym celu zapewne, aby uświadomić odbiorcy Ewangelii, że czyn Jezusa nie jest łatwy do zrozumienia. Użyte wyrażenia są podobne, co w wierszach 12 i 17, które również podkreślają potrzebę dobrego zrozumienia czynu Jezusa. $\mathrm{Z}$ tamtych wierszy mogly być zaczerpnięte.

W. 8. Ciąg dalszy protestu Piotra „Nie będziesz mi mył nóg, na wieki” zawiera konstrukcję spotykaną częściej u Jana: „nie (...) na wieki” (ou me ... eis ton aiona: $6+1)$. Bardzo podobne zwroty, „na wieki” połączone $z$ inaczej brzmiącym zaprzeczeniem, spotykamy jednak u synoptyków (Mk 3, 29; 11, 14-Mt 21, 19). Co więcej, wyrażenia omawiane wprowadza Jan przy solennych zapowiedziach $(4,14 ; 8,51 \mathrm{n} ; 10,28 ; 11,26)$ - a nie przy proteście czy zarzekaniu się, jak tutaj. Takie użycie znajdziemy za to poza Ewangelią, u św. Pawła (1 Kor 8, 13).

Wynika stąd, że i to zdanie Piotra ma cechy autentyczności. Odpowiedź Jezusa „Jeśli cię nie umyję, nie masz udziału ze mną” również należy do pierwotnego dialogu, nie mając w Ewangelii żadnej paraleli.

W. 9: w odpowiedzi Piotra „(Panie), nie tylko nogi, ale i ręce i głowę” także brak cech języka ewangelisty.

W. 10. Słowa Jezusowe: „Wykąpany nie potrzebuje się myć, (oprócz nóg), ale jest czysty cały" nie mają znamion stylu Janowego. Wyrazów umieszczonych w nawiasie, ,„oprócz nóg”, brak w szeregu ważnych rękopisów greckich i łacińskich, tak że trzeba je uznać za dodatek późniejszy. Jego celem było powiązanie tego zdania z poprzednimi. Samo w sobie nie łączy się ono bowiem z nimi w sposób konieczny, przeciwnie, ma charakter aforyzmu łatwego do przekazania osobno. Co więcej, treść zdania niezbyt pasuje do całości. Nie mówi wcale o umyciu nóg rękami Jezusa; walor zbawczy ma tu zanurzenie calkowite (,wykąpany" - leloumenos), gdy w wierszach poprzednich chodziło o umycie części ciała (gr. nipto).

Sentencja zawiera trzy terminy często używane w Piśmie świętym odnośnie czynności rytualnych: „czysty” (katharos), „myć” (nipto) i „kąpać” (louo). Pochodzi więc zapewne $\mathrm{z}$ jakiejś dysputy na temat obmyć rytualnych. Jezus twierdził, że całkowite zanurzenie znosi potrzebę innych obmyć. Zdanie to, podobnie jak wiele innych luźnych „logiów”, pojedynczych wypowiedzi Jezu- 
sa przekazanych przez Ewangelie, zostało dołączone do innych zdań, które dotyczyły podobnego tematu - w tym wypadku obmycia.

W. 10b-11 dodatkowo wyjaśniają zastosowanie powyższego powiedzenia, „logionu” do sytuacji, zawierając w szczególności aluzję do zdrady Judasza. Skoro logion ów pochodził skądinąd, jego aplikacja musiała wyjść spod pióra ewangelisty. W. 11 jest wprost sformułowany jak komentarz redakcyjny.

W. 12 nie zawiera cech języka Janowego i kontynuuje opis wydarzeń z w. $4-5$.

W. 13 sam w sobie nie wiąże się $z$ kontekstem. Słowa „nazywacie mnie Panem i Nauczycielem i dobrze mówicie, bo nim jestem" mogły paść przy innej okazji - raz jeszcze pojedynczy „logion” dołączony został do większej całości. Warto zauważyć, że słowo „Pan” nie ma w tym wierszu znaczenia chrystologicznego, chodzi raczej o tytuł porównywalny z ,nauczycielem”. Według Talmudu uczniowie niekiedy nazywali swego mistrza mar (,pan”). Jezus mógł użyć tu słów marî i rabbî (por. Mt 7, 21; Mk 11, 3; Mk 14, 14).

W. 14-15 komentują w. 13 i zmierzają do połączenia go z całością - pochodzą więc od ewangelisty. Konstrukcje zdań są typowe dla jego pism i nigdzie poza nimi w NT nie występują: ,,jeżeli + czasownik + ,il + ten sam czasownik (6 razy w Ewangelii i 1 raz w 1 Liście św. Jana); 2 razy ,ja (..) i wy” (6 razy w Ewangelii; samo ,ja...wy” zob. w. 7); , ,jako (...) i" + zaimek (7 razy).

Celem tych zdań jest pokazanie chrześcijanom, że czyn Jezusa należy naśladować. Tego rodzaju naśladowanie nakazywał oczywiście sam Jezus, ale konkretne sformułowanie nakazu w tych właśnie wierszach pochodzi od ewangelisty. Jest to dobry przykład metody pisarskiej autorów natchnionych, którzy wyjaśniając słowa Jezusa na użytek odbiorców często formulowali komentarz jako dalszy ciąg jego własnych słów. Szczególnie autor czwartej Ewangelii ujmował nauki Jezusa w swoim własnym języku i stylu, dążąc nie do samej historycznej rekonstrukcji, lecz do możliwie pełnego pokazania osoby Chrystusa w świetle wiary.

W. 16 to kolejny osobny aforyzm włączony w całość. Znamy go skądinąd (Mt 10, 24-Łk 6, 60 por. 20, 27; także J. 15, 20). Dwukrotne „zaprawdę" (amen, amen) występuje tylko w czwartej Ewangelii.

W. 17. Słowa „Jeśli to wiecie, szczęśliwi jesteście” są dalszym ciągiem słów Jezusa z w. 12. „Szczęśliwi” („błogosławieni” - makarioi) to słowo często przez Jezusa używane, natomiast u Jana rzadkie (J 20, 29).

Dalsze słowa, ,jeżeli to czynić będziecie" należy uznać za dopisek powtarzający treść w. 14-15. Zdanie „szczęśliwi jesteście” łączy się w wersji obecnej z dwoma różnymi zdaniami warunkowymi, co też nie jest naturalne; tym bardziej trzeba więc odsunąć jedno z nich jako późniejsze.

W. 18-20 noszą cechy stylu Janowego i nie wiążą się treścią z obmyciem nóg. Wprowadził je w tym miejscu ewangelista. W. 20 zawiera znów aforyzm Jezusowy znany z tradycji synoptycznej; jego przekład z oryginału aramejskiego posługuje się jednak terminami typowymi dla języka czwartej Ewangelii („,który mnie posłal” - ho pempsas me - powiedziane o Bogu: 24 razy; „przyjmować kogoś” — lambano tina - 8 razy w Ewangelii i 1 w 1 Liście - nigdzie zaś indziej w NT). 


\section{TRADYCJA PIERWOTNA}

Zbierając powyższe obserwacje można podać przypuszczalne brzmienie pierwotnego opisu umycia nóg. Ma on wyraźną budowę symetryczną; takie odkrycie dowodzi, że analiza oparta na statystyce słownictwa i stylu bynajmniej nie dała rezultatów przypadkowych:

\section{(Przed Paschą)}

I wstał od wieczerzy

i złożył szaty a wziąwszy prześcieradło opasał się. Następnie nalał wody do miski

i zaczął myć nogi uczniów prześcieradłem, którym był opasany.

(Piotr): (Panie), ty mi myjesz nogi?! Nie będziesz mi mył nóg, na wieki!

(Jezus): Jeśli cię nie umyję, nie masz udziału ze mną.

(Piotr): (Panie), nie tylko nogi, ale i ręce i głowę!

Kiedy zaś umył ich nogi, wziął swe szaty

i znów spoczął.

I rzekł im: Czy rozumiecie, co wam uczyniłem? Jeśli to wiecie, szczęśliwi jesteście.

Ponadto w. 10. 13. 16. 20 zawierają pojedyńcze logia, z których skorzystał autor Ewangeli, aby rozwinąć wypowiedzi Jezusa i objaśnić jego intencje. Te logia też należą do materiału źródłowego z tradycji pierwotnej.

Tekst mimo budowy symetrycznej, służącej zapewne łatwiejszemu zapamiętaniu, zawiera liczne szczegóły wychodzące poza schemat i przypomina stylem mniej opracowane literacko opowiadania o czynach Jezusa zawarte w Ewangeliach synoptycznych. Nie może różnić się wiele od relacji naocznego świadka.

Historyczna wartość opisu byłaby trudna do podważenia. Czynność Jezusa jest zaskakująca, oryginalna i niełatwa do zrozumienia. Słowa objaśniające czynność nie wiążą się z żadną późniejszą koncepcją teologiczną. Mycie nóg przez mistrza zamiast przez służącego było czymś zupełnie nieprzewidzianym, powinno wywołać protesty; reakcje Piotra zgodne są z temperamentem tego apostoła (por. np. Mk 8, 22n; 9, 5). Szczegóły mycia nóg opisano realistycznie.

\section{SENS UMYCIA NÓG}

Z odtworzonego wyżej pierwotnego przekazu o umyciu nóg wynika, że jego sens objaśniony został przez słowa tworzące oś całego opowiadania ,,jeśli cię nie umyję, nie masz udziału ze mną". Następnie sama natura czynności, nawet bez komentarza, wydaje się znacząca. Na tej podstawie wyjaśnić da się sens czynności zamierzony przez samego Jezusa. 
Uczniowie otrzymać mają „udział z Jezusem”. Słowo „udział” ma w ST znaczenie szerokie i na ogół pospolite; oznacza między innymi udział w dobrach albo wspólnotę z kimś (2 Sm 20, 1: z Dawidem). „Udział i dziedzictwo” to część ofiar zastrzeżona lewitom.

W Nowym Testamencie sens teologiczny jest wyraźniejszy. Dz 8,21 mówi: „nie masz żadnego udziału ani dziedzictwa w tym dziele” (w posłudze apostołów); Kol 1,12: „udział i dziedzictwo świętych w światłości”; Ap 22, 19: „zabierze udział jego od drzewa życia”. Zwrot „mieć udział” znajdziemy w Ap 20, 6: „błogosławiony i święty mający udzial w zmartwychwstaniu” oraz w kontekście negatywnym w Mt 24, 51; Łk 12, 46 (,,wyznaczy mu udział z obludnikami”) i w Ap 21, 8 (,udział w jeziorze ognia”); w tych dwóch ostatnich przypadkach można tłumaczyć meros jako „miejsce”. Najwyraźniejszy sens teologiczny znajdziemy zatem w Apokalipsie, ale księga ta, powstała po roku 90, może już odzwierciedlać sposób mówienia ukształtowany przez chrześcijan, a może jest to nawet jakiś komentarz do słów Jezusa z J 13, 8 .

Głębszą interpretację znaleźć można też w dokumentach pozabilibjnych. W targumach do Rdz 15, 1 (Neofiti, Pseudo-Jonatana, Fragmentaryczny) Abraham mówi o swym „udziale w świecie, który ma przyjść". Targumy, aramejskie parafrazy ST, w wielu miejscach odbijają żydowskie myślenie religijne z czasów bliskich Jezusowym — w tym miejscu świadczą o łączeniu terminu „udział" z wyobrażeniami eschatologicznymi. Podobną ideę znajdziemy również w Misznie (Talmud Jerozolimski, traktat „Szabat”, I, 3).

W świetle tych przykładów nie samo słowo „udzial” jest najważniejsze, ale $\mathrm{z}$ kim ten udział się ma. Jednocześnie słowo to może sugerować udział w zbawieniu, a zwłaszcza życie przyszłe. „Udział z Jezusem” to bycie z nim teraz i na wieki. Udział taki ofiarował Jezus apostołom przez szokujący gest umycia im nóg.

Mycie nóg, a mianowicie stóp zabrudzonych chodzeniem, było znakiem poddaństwa, dokonywał go niewolnik, ewentualnie żona i córki pana domu; uczniowie mogli myć nogi mistrza (Talmud Babiloński, traktat Berakot-Btogosławieństwa - 7b). Jezus odwrócił te zasady myjąc nogi swoim uczniom. Był to akt służby, a co więcej niewolniczego poniżenia, podkreślonego jeszcze przez nagość, zdjęcie szat (por. np. Iz 20, 3n). O takim zrozumieniu czynu Jezusa świadczy też protest Piotra.

Podanie wody do umycia nóg było również aktem gościnności (np. Łk 7 , 44). Czasami mowa wręcz o myciu nóg gościom na znak czci (por. 1 Tm $5,10 \mathrm{i}$ apokryfy ST: Testament Abrahama 3 oraz Józef $i$ Aseneth 7, 1; 13, 12; 20, 1-5). Jezus dopełnił zatem także aktu nadzwyczajnej gościnności, która w świetle dalszych jego słów przybiera charakter zapowiedzi przyjęcia na ucztę eschatologiczną.

Umycie nóg towarzyszyło ostatniemu wspólnemu wieczorowi z uczniami. Wlaśnie wtedy (choć czwarta Ewangelia o tym nie wspomina) nastąpiło ustanowienie Eucharystii. Umycie nóg jawi się jako jej konieczny wstęp. Samo obmycie przygotowuje do uczty w sposób zewnętrzny, ale Jezus nadał mu skuteczność dalej idącą, powiązał je wprost z darami zbawczymi, ze swoją obecnością. 
Można porównać umycie nóg uczniom do czynności sakramentalnych jak ona, czynność ta, udziela darów zbawczych poprzez znak zewnętrzny. U progu Misterium Paschalnego apostołowie otrzymują dar „udziału z Jezusem"; czym ten dar jest, odsłonią w pełni Eucharystia, męka i zmartwychwstanie. Umycie nóg jawi się jako pierwszy krok na tej drodze, a zarazem zapowiedź jej celu.

Nie sposób przeoczyć, że dary te powiązane zostały z uniżeniem Jezusa, z jego pokorną służbą. Jezus przedstawiał się jako sługa i chrystologia NT myśl tę wyraźnie podejmuje (zob. Mk 9, 35; 10, 43-45; Łk 7, 44; 12, 37; 22, 27; Flp $2,6-8 ; 1 \mathrm{P} 4,13)$. Jego służbie i uniżeniu zawdzięczamy zbawienie. Umycie nóg okazuje się czynnością symboliczną, której strona materialna wciela posługę Jezusa, zaś skutek jest rezultatem jego czynu zbawczego.

W tym świetle zrozumiałe są końcowe słowa Jezusa: „Czy rozumiecie, co wam uczyniłem? (...) Jeśli to wiecie, szczęśliwi jesteście”. Szczęściem i błogosławieństwem jest zrozumieć to, że Jezus przyjął nas do siebie, że wysłużył nam życie wieczne.

\section{INTERPRETACJA EWANGELISTY}

Mogliśmy stwierdzić, że przy redagowaniu Ewangelii przekaz starszy został istotnie rozbudowany. Na tę rozbudowę składają się dwojakiego rodzaju elementy:

a) Po pierwsze, rozszerzono słowa Jezusa opierając się na jego słowach wypowiedzianych przy innych okazjach (w. 10a. 13,16. 20) oraz używając wyrażeń, które można znaleźć także w przekazie pierwotnym (w. 7.11b. 14). Autor Ewangelii nalega przy tym na wpływ wydarzenia, na sytuację uczniów oraz na jego sens przykładowy, pedagogiczny (w. 10. 11b. 14-15. 16. 17b. 18b). Jezus jest dla uczniów Panem. Styl „Janowy” przejawia się w użyciu formuł wprowadzających zdania dialogu (w. 6-10.16) oraz w konstrukcji zdań (w. 7. 11b. $14-15.18 \mathrm{a})$.

b) Po drugie, dodano refleksje teologiczne na temat osoby Jezusa i jego świadomości oraz relacji z Ojcem (w. 1.3. 19 oraz przekład w. 20). Styl odznacza się obecnością wielu czasowników o specyficznym znaczeniu teologicznym.

Te dwa kierunki opracowania wydają się odrębne i można by uznać je za dzieło różnych osób, nawet jeśli współpracowały one ze sobą. Można sądzić, że najpierw powstal tekst z w. 4-17, który mógl być połączony z zapowiedziami zdrady Judasza z w. 2 i 18, a także z określeniem czasu na „przed Paschą”. Potem dokonano teologicznego opracowania całości. Spraw tych nie da się tu rozważyć szerzej, a to ze względu na ich związek z zawiłym problemem historii powstania tej Ewangelii oraz jej autorstwa. Wspomnijmy tylko, że analiza powyższa sugeruje współpracę między mistrzem, głównym autorem, a sekretarzem (a może i kontynuatorem jego pracy).

Dla objaśnienia umycia nóg większe znaczenie mają uwagi wplecione w w. 4-17 niż pozostałe, które odnoszą się do osoby i misji Jezusa w ogóle. Ewan- 
gelista podkreślił, że czynność Jezusa posiada sens głębszy i że jego rozumienie wymaga wysiłku (w. 7). Pozwala to szukać powiązania umycia nóg z całością Misterium Paschalnego, z tym co można było „zrozumieć później”. Odruchowe rozumienie mycia nóg jako przede wszystkim uniżenia byłoby niewystarczające.

Słowa z w. 10 o czystości i wartości obmycia pierwotnie dotyczyły raczej kwestii rytualnych. W kontekście Ewangelii i jej czasów wyraźnym się stało, że zanurzenie, kąpiel, o której tam mowa, też ma sens głębszy. Słownictwo dotyczące oczyszczeń rytualnych było później przez chrześcijan stosowane do innych celów. Słowa użyte w J 13, 10 kojarzono bądź ze chrztem (Dz 22, 16; 1 Kor 6, 11; Ef 5, 26; Tt 3, 5; Hbr 10, 22; Ap 1, 5?), bądź też z oczyszczeniem przez dzieło Jezusa i przez jego krew (1 Jn 1, 7. 9; 3, 5; 4, 10 ; Ap 7, 14; 22, 14; J 15, 3 - por. też Tt 2, 14; Hbr 1, 3; 9, 14; 10, 22; 12, 24 i jeszcze Hbr 9, 22; $1 \mathrm{P} 1,2 ; 2 \mathrm{P} 1,9)$. W tym kontekście w. 10 też zaczął sugerować sens zbawczy względnie sakramentalny umycia nóg, choć raczej na zasadzie luźnego skojarzenia. Wynika też z niego, że po chrzcie, zanurzeniu, dalsze obmycia są już zbędne.

Wprowadził wreszcie ewangelista nakaz naśladowania pokory Jezusa. Sama czynność symboliczna dokonana wobec apostołów jest wprawdzie powiązana ze zbawczymi czynami Jezusa i nie może być w pełni powtórzona. Mogą jednak wyznawcy brać z niej przykład pokornej służby, „myć sobie nawzajem nogi”. Sens przenośny jest tu wyczuwalny, chodzi o zachętę do wszelkich form służby bliźnim.

Umycie nóg posiada zatem sens bogaty i wieloraki, trudny do zamknięcia w krótkiej formule. Czynność Jezusa pokazała jego postawę służby: służby, która rzeczywiście zapewnia nam zbawienie i życie wieczne. Jako akt pokory jest też umycie nóg przykładem dla nas.

Warszawa

MICHAE WOJCIECHOWSKI

\section{LITERATURA}

O J 13, 1-20 pisano wyjątkowo dużo. Z komentarzy do Ewangelii za najważniejsze uznać tu można następujące: R. Schnackenburg, Das Johannesevangelium, Herders Theologischer Kommentar zum NT IV/1-3, t. 1-3 (najdostępniejszy jest przedruk z NRD: wyd. 3 Leipzig 1979); M.-E. Bois m ard, A. La mouille, Synopse des quatres Évangiles en francais, t. 3: L'Évangile de Jean, Paris 1977; R. Bultmann, Das Evangelium des Johannes, wyd. 20, Göttingen 1985; R. E. B rown, The Gospel according to John, Anchor Bible 29-29A, Garden City 1966. Po polsku L. Stachowiak, Ewangelia wedtug św. Jana, Pismo Święte NT 4, Poznań 1975.

Różne kierunki dawnej i nowszej egzegezy tego tekstu zostały przedstawione przez G. Richtera, Die Fusswäschung im Johannesevangelium. Geschichte ihrer Deutung, Regensburg 1967. Z artykułów nowszych wymienić 
należy: J. Beutler, Die Heilsbedeutung des Todes Jesu im Johannesevangelium nach Joh 13, 1-20, w: Der Tod Jesu, Questiones Disputatae 74, FreiburgB 1976, 188-204; E. Cothe net, Gestes et actes symboliques du Christ dans le IV évangile, w: Gestes et paroles dans les diverses familles liturgiques, Conférence St. Serge 1977, Ephemerides Liturgicae, Roma 1978, 95-116; P. Grelot, L'interpretation penitentielle du lavement des pieds, w: L'homme devant Dieu, Mél. H. de Lubac, Lyon 1963, 75-91; A. J. Hultgre n, The Johannine Footwashing (13, 1-11) as a Symbol of Eschatological Hospitality, „New Testament Studies" 28 (1982) 3, 539-46; S. M. Schneiders, The Foot Washing (John 13, 1-20), an Experiment in Hermeneutics, „Catholic Biblical Quaterly” 43 (1981) 1, 76-92; F. F. Segovi a, John 13, 1-20, the Footwashing in the Johannine Tradition, "Zeitschrift für die Neutestamentliche Wissenschaft" 73 (1982) 1, 31-51; H. Thy en, Johannes 13 und die ,kirchliche Redaktion des vierten Evangeliums, w: Tradition und Glaube, Fs. K. G. Kuhn, Göttingen 1971, 343-56; M. Woj ciechow s ki, La source de Jean 13, 1-20, „New Testament Studies” 34 (1988) 1, 135-141 (wykorzystane zwłaszcza w sekcji dotyczącej analizy literackiej). Propozycje bardziej kontrowersyjne to np. J. D. G. D un n, The Washing of the Disciples Feet in John 13, 1-20, "Zeitschrift für die Neutestamentliche Wissenschaft" 61 (1976), 247-52; J. D. M. Derrett, „Domine, tu mihi lavas pedes?” Studio su Giovanni 13, 1-30. „Bibbia et Oriente" 119 (1979), 14 -42; M. S a b bé, The Footwashing in Jn 13 and its Relation to the Synoptic Gospels, „Ephemerides Theologicae Lovanienses” 58 (1982), 279-308; H. Weiss, Foot Washing in the Johannine Community, „Novum Testamentum” 21 (1979), 298-325.

Wykorzystano też zbiór tekstów rabinicznych ilustrujących NT: P. Billerbeck, H. L. Strack, Kommentar zum Neuen Testament aus Talmud und Midrasch, t. 1-4, München 1922-28+ indeksy t. 5-6, München 1956-61.

\section{Ks. Tomasz Hergesel}

\section{BIBLIA CZYTANA W AFRYCE}

Północno-wschodni skrawek Afryki - użyźniany wylewami Nilu, zorganizowany gospodarczo i rozwinięty kulturowo - przyciągal ludy koczownicze, które znajdowały tu bogaty rynek, a nieraz i ocalenie. Tak było w czasach patriarchów. W kierunku piramid wędrował Abraham, a Józef sprowadził do Egiptu swoich najbliższych zapewniając im dostatek. W czasach trudnych dla potomków Jakuba nad Nilem urodził się Mojżesz. Wykształcony na dworze faraona i przyzwyczajony do życia na pustyni spełnił misję zleconą mu przez Pana. Ewangelista Mateusz ukazuje „patriarchę” Nowego Testamentu, Józe- 